\title{
IMPLEMENTASI MEDIASI PENAL SEBAGAI PERWUJUDAN NILAI- NILAI PANCASILA GUNA MENDUKUNG SUPREMASI HUKUM DALAM RANGKA PEMBANGUNAN NASIONAL
}

\author{
Yusriando \\ Dosen Universitas Prima Indonesia \\ yusriando@unprimdn.ac.id
}

\begin{abstract}
Abstrak
Implementasi Undang-Undang Mediasi Penal penting eksistensinya menyelesaikan perkara di luar pengadilan. Substansi mediasi penal lahir, tumbuh, berkembang dan digali dari bumi Indonesia lewat kearifan lokal hukum adat (local wisdom) dan nilai-nilai Pancasila. Di Indonesia, dalam perspektif nasional mediasi penal diatur secara terbatas dan parsial dalam Peraturan dan Surat Kapolri serta Peraturan Menteri. Dari perspektif praktik, mediasi penal dilakukan lewat diskresi aparat penegak hukum, peradilan adat, yurisprudensi Mahkamah Agung dan putusan Pengadilan Negeri. Diperlukan adanya optimalisasi penerapan nilai-nilai Pancasila dalam hukum karena nilai-nilai yang hidup tersebut secara keseluruhannya termaktub pada sila-sila Pancasila. Apabila hal ini dilakukan, hukum bersangkutan relatif dapat diterima oleh karena masyarakat mengganggap bahwa hukum mencerminkan nilai keadilan, kepastian hukum, ketertiban dan mengandung kemanfaatan bagi masyarakat sehingga dapat mendukung supremasi hukum dalam rangka pembangunan nasional.
\end{abstract}

Kaca Kunci: Mediasi Penal, Nilai-Nilai Pancasila, Supremasi Hukum dan Pembangunan Nasional

\begin{abstract}
Implementation of Penal Law Mediation important existence out of court settlement to the case. The substance of penal mediation was born, grow, develop and earth excavated from Indonesia through the local wisdom of indigenous (local wisdom) and the values of Pancasila. In Indonesia, the national perspective penal mediation is set in a limited and partial in the Regulations and the Letter of the Chief of Police and regulation. From the perspective of practice, penal mediation is done through the discretion of law enforcement officials, customary justice, the jurisprudence of the Supreme Court and the District Court's decision. Necessary to optimize the application of the values of Pancasila in the law because it values the life as a whole contained in the principles of Pancasila. If this is done, the law in question is relatively acceptable because people assume that the law reflects the values of justice, rule of law, order and contain the benefits to society so as to support the rule of law in the context of national development.
\end{abstract}

Keywords : Penal mediation, values of Pancasila, the Rule of Law and National Developmen 


\section{A. Pendahuluan}

Ketentuan Pasal 1 ayat (3) amandemen ketiga UUD NRI 1945 menyatakan bahwa, "Negara Indonesia adalah Negara Hukum". Negara hukum adalah negara yang mendasarkan segala sesuatu, baik tindakan maupun pembentukan lembaga negara pada hukum tertulis atau tidak tertulis. ${ }^{1}$ Ditinjau dari perspektif praktik peradilan di Indonesia dan produk legislasi terutama dalam ranah hukum pidana, nilai-nilai Pancasila $^{2}$ yang terkandung dalam konsep kemanusiaan yang adil dan beradab serta keadilan sosial bagi seluruh rakyat Indonesia serta dikorelasikan dengan sila kerakyatan yang dipimpin oleh hikmat kebijaksanaan dalam permusyawaratan/perwakilan senyatanya masih belum memberikan perwujudan mendalam. Tolok ukur nilai-nilai Pancasila dalam proses penegakan hukum di Indonesia baik dalam tahap legislasi (pembuatan peraturan perundangundangan), tahap aplikasi/implementasi (penegakan hukum yang dilakukan oleh aparat penegak hukum seperti diatur dalam sistem peradilan pidana mulai dari lembaga kepolisian,lembaga kejaksaan dan lembaga pengadilan), serta dalam tahap administratif/pelaksanaan pidana (dilakukan oleh lembaga pemasyarakatan) menimbulkan implikasi dalam penerapannya.

Tegasnya, dimensi konteks di atas dalam proses penegakan hukum yang menjunjung tinggi supremasi hukum relatif belum mewujudkan nilainilai Pancasila sehingga konsekuensi logisnya akan berkorelasi terhadap pembangunan nasional. Problematika ini sangat dirasakan para pakar, akademisi, masyarakat pencari keadilan (justiabelen),

1 Lemhannas RI. 2016. Jakarta: Materi Pokok Bidang Studi Hukum \& HAM, hIm. 16

2

Lemhannas RI. 2016. Jakarta: Modul Bidang Studi Pancasila dan UUD NRI Tahun 1945, hlm. 99100 menyebutkan bahwa Nilai-Nilai Pancasila adalah Nilai Religius, Nilai Kekeluargaan, Nilai Keselarasan, Nilai Kerakyatan dan Nilai Keadilan. serta ketika seorang terdakwa diputus didepan sidang pengadilan. Konsep ideal tatanan negara hukum adalah hukum harus dijadikan panglima dalam dinamika kehidupan kenegaraan. ${ }^{3}$ Hukum pada dasarnya berkorelasi dengan sistem hukum dan merupakan dasar utama berdirinya suatu negara. Hukum merupakan sumber tertinggi (supremasi hukum) dalam mengatur dan menentukan mekanisme hubungan hukum antara negara dan masyarakat atau antar anggota masyarakat satu dengan yang lain. ${ }^{4}$

Konteks dan dimensi di atas selaras ketentuan Pasal28Dayat1UUDNRITahun 1945 hasil amandemen yang berbunyi: "Setiap orang berhak atas perlakukan yang sama dihadapan hukum sehingga ketidakmampuan secara ekonomi tidak menghalangi seseorang mendapatkan haknya tersebut". Konsekuensi logisnya, secara konstitusional negara Indonesia menjamin setiap orang mempunyai kedudukan yang sama dihadapan hukum (equality before the law). Prinsip hukum ini bukan hanya merupakan prinsip persamaan kedudukan hukum yang paling mendasar, tetapi juga merupakan salah satu hak dasar manusia, karena hak itu berhubungan langsung dengan harkat dan martabat manusia.

Kebijakan pembangunan nasional in casu pembangunan hukum nasional harus bertitik tolak dari konstitusi sebagai the supreme law of the land dengan mengerahkan segenap potensi dan kemampuan sumber daya yang dimiliki serta memperkirakan kondisi yang mempengaruhinya baik dalam skala nasional, regional maupun global serta tertib langkah dalam setiap usaha tersebut dengan tujuan pembangunan nasional.

3 Jimmly Asshidiqie. 2007. Jakarta: Pokok-Pokok Hukum Tata Negara Indonesia Pasca Reformasi, hlm. 297

4

Bagir Manan. 2003. Jakarta: Teori dan Politik Konstitusi, hIm. 238 
Diperlukan langkah strategis yang mencakup seluruh elemen sistem hukum yaitu, substansi hukum (legal substance), struktur hukum (legal structure) dan budaya hukum (legal culture). ${ }^{5}$

Dikaji dari perspektif sejarah hukum pada awalnya tidak dibedakan antara hukum pidana dan hukum perdata, sehingga setiap perkara memungkinkan dilakukan mediasi. Kemudian dimensi ini berkembang dan ditinggalkan dimana dibedakan antara hukum pidana dan hukum perdata. Akan tetapi, perkembangan masyarakat terkini terjadi praktik kasus pidana diselesaikan juga melalui mekanisme musyawarah atau perdamaian melalui bentuk implementasi mediasi penal. Aspek ini ada di dalam masyarakat sebagai penerapan nilai kearifan lokal (local wisdom) maupun dalam sistem pemidanaan guna menuju

$5 \quad$ Lawrence W. Friedman. 1984. New York: American Law: An invaluable guide to the many faces of the law, and how it affects our daily our daily lives, hlm. 1-8, menentukan pengertian struktur adalah, "The structure of a system is its skeleton framework; it is the permanent shape, the institutional body of the system, the though rigid nones that keep the process flowing within bounds..", kemudian substansi dirumuskan sebagai, "The substance is composed of substantive rules and rules about how institutions should behave," dan budaya hukum dirumuskan sebagai, "The legal culture, system their beliefs, values, ideas and expectation. Legal culture refers, then, to those ports of general culture customs, opinions ways of doing and thinking that bend social forces toward from the law and in particular ways. "Ketiga elemen tersebut saling mempunyai korelasi erat. Lawrence M. Friedman lebih lanjut mendeskripsikan ketiga elemen sistem hukum tersebut diumpamakan sebuah mesin dimana budaya hukum sebagai bahan bakar yang menentukan hidup dan matinya mesin tersebut. Konsekuensi aspek ini maka budaya hukum begitu urgen sifatnya. Oleh karena itu, tanpa budaya hukum, sistem hukum menjadi tidak berdaya, seperti seekor ikan mati yang terkapar di dalam keranjang, bukan seperti seekor ikan hidup yang berenang di lautan. Terminologinya, "without legal culture, the legal system is inert - a dead fish lying in a basket, not a living fish swimming in its sea". keadilan restoratif sebagai proses pembaruan hukum dalam rangka pembangunan hukum nasional.

Hakikat penyelesaian perkara melalui mediasi penal dapat dilihat dalam bagan 1 berikut: 


\section{Bagan 1 \\ Bentuk Penyelesaian Perkara}

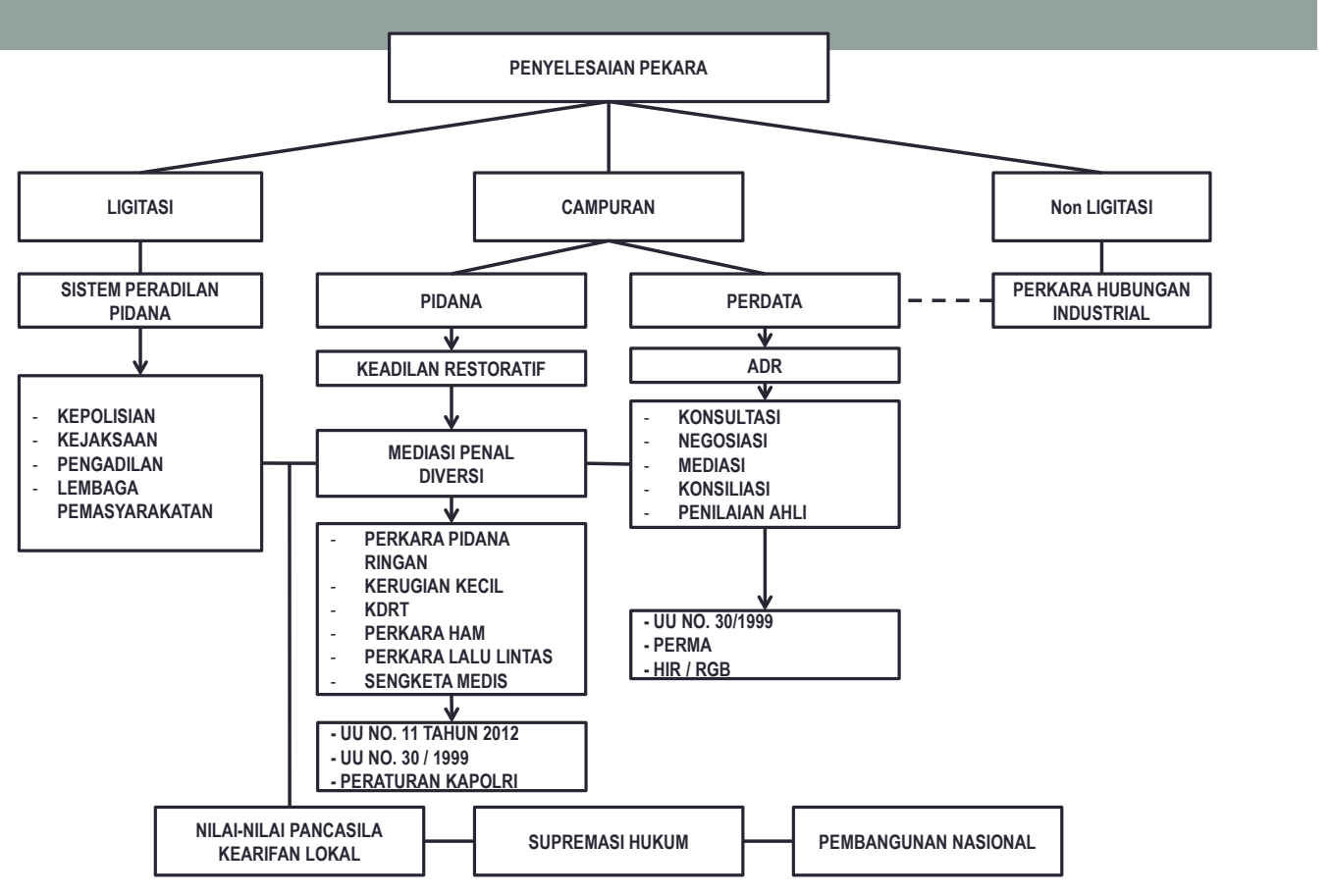

Mediasi penal selaras dengan perkembangan baru dalam penegakkan hukum dimana tidak selalu seorang pelaku harus diproses, diadili dan dihukum melalui konsep peradilan restorative justice sebagai bentuk penyelesaian perkara di luar pengadilan (Alternative Dispute Resolution). Menurut Stephenson, Giller dan Brown keadilan restoratif bertujuan memperbaiki tindak kejahatan dengan menyeimbangkan pelaku, korban dan komunitas dalam bentuk mediasi penal (victim offender mediation), restorative conference, family group conferencing, community panel meeting. ${ }^{6}$

Konsepsi dan implementasi mediasi penal sebenarnya berkorelasi sila Pancasila sebagaimana termaktub dalam sila keempat dan kelima. Konteks ini dapat diartikan sebagai cara atau langkah bangsa Indonesia untuk mewujudkan tercapainya tujuan hidup berbangsa dan 6 Stephenson, Giller dan Brown. 2007. Portland: Effective Practice in Youth Justice, hlm. 163-166 bernegara, senantiasa merupakan suatu kesatuan dengan sila-sila yang lain, dan pula dilandasi adanya filosofi nilai religius, nilai kekeluargaan dan nilai keselarasan sebagaimana sila pertama, kedua dan ketiga dari Pancasila.

Prinsip dasar restorative justice melalui mediasi penal menemukan pijakannya dalam nilai Pancasila yang menjunjung nilai keseimbangan dan kemaslahatan baik terhadap pelaku kejahatan maupun korban. Ironis sekali setiap tindak pidana harus berujung dipenjara sehingga daya tampung rutan dan lapas menjadi penuh (over capacity), padahal efektifitas pidana penjara belum tentu memberikan efek jera (detterent effect) dan cenderung memberikan stigma sosial baik dari sisi mantan terpidana saat keluar dari penjara maupun ketika kembali bersosialisasi kemasyarakat.

Hazairin Alamsyah Harahap mengkritik pidana penjara kemudian memberikan sebuah gagasan "Negara tanpa Penjara". 
Wacana ini timbul karena faktanya banyak lembaga pemasyarakatan tidak memberikan manfaat dan efek jera secara treatment oriented melainkan sebaliknya deterent aspect, sehingga muncul pelaku kejahatan baru atau recidivis. Hazairin berpendapat bahwa pidana penjara bukan hanya mengakibatkan perampasan kemerdekaan, melainkan juga menimbulkan akibat-akibat negatif, bahkan narapidana akan menjadi lebih jahat lagi dari yang sebelumnya setelah keluar dari penjara, terpidana cenderung akan melakukan kejahatan lagi setelah keluar dari penjara, dan juga menyebabkan dehumanisme, berisiko terjadi prisonisasi, menimbulkan cap jahat (stigma), bahkan masyarakat akan menolak dengan kehadiran mantan narapidana. ${ }^{7}$

Banyak hal yang perlu direkonstruksi dalam sistem peradilan pidana di Indonesia, karena tidak semua kasus pidana berujung di pengadilan terutama tindak pidana ringan, perkara kecil dan kejahatan ringan ${ }^{8}$ dimana antara korban, pelaku dan masyarakat masih dapat direstorasi sehingga kondisi yang telah rusak bisa diperbaiki kembali dan timbul upaya win-win solution sesuai dengan paradigma mediasi penal. Keadilan sosial bagi seluruh rakyat Indonesia dalam sistem kerakyatan yang dipimpin oleh hikmat kebijaksanaan yang berasaskan musyawarah setidaknya dapat tercermin dalam peradilan di Indonesia, tanpa harus

7 Harahap, Hazairin Alamsyah. 1981. Jakarta: Tujuh Serangkai Tentang Hukum, hlm. 2

8 Tindak Pidana Ringan (Tipiring) dalam ketentuan Pasal 205 Undang-Undang Nomor 8 Tahun 1981 tentang Kitab Undang-Undang Hukum Acara Pidana (KUHAP) merupakan tindak pidana yang diancam dengan pidana penjara atau kurungan paling lama 3 (tiga) bulan dan denda sebanyak-banyaknya Rp. 7.500,00 (tujuh ribu lima ratus rupiah). Kemudian kejahatan ringan (lichte misdrijven) seperti diatur dalam Kitab UndangUndang Hukum Pidana (KUHP) berupa Pasal 302 tentang penganiayaan ringan terhadap hewan, Pasal 315 (penghinaan ringan), Pasal 353 (penganiayaan ringan), Pasal 364 (pencurian ringan), Pasal 373 (penggelapan ringan), Pasal 379 (penipuan ringan), Pasal 482 (penadahan ringan), dan lain sebagainya. diselesaikan melalui dimensi retributif dan berujung pada pidana penjara, sehingga nilai-nilai tersebut dapat terwujud nyata dalam sistem peradilan pidana yang "memanusiakan" dalam bentuk asas keseimbangan monodualistik yaitu keseimbangan antara asas kemasyarakatan dan asas individualistik.

Dimensi nilai mediasi penal sebenarnya berakar keadilan restoratif dari kearifan lokal hukum adat Indonesia. Dalam praktik sosial masyarakat Indonesia, mediasi penal sudah lama dikenal dan telah menjadi tradisi seperti pada masyarakat Papua (budaya bakar batu), Aceh (peradilan gampong), Bali (lembaga adat dalam awig-awig desa), Nusa Tenggara Barat (lembaga begundem), dan lain

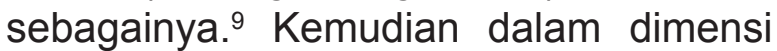
yuridis, mediasi penal diatur secara parsial, terbatas dan tatarannya masih di bawah undang-undang, seperti dalam Instruksi Presiden (Inpres) dan Peraturan Kapolri. Dalam praktik peradilan terdapat dalam yurisprudensi Mahkamah Agung, Putusan Pengadilan Negeri, kemudian pula terjadi dalam praktik sidang adat dan juga diatur dalam Rancangan UndangUndang (RUU) Kitab Udang-Undang Hukum Pidana Indonesia Tahun 2015. ${ }^{10}$

9 Lilik Mulyadi. 2015. Bandung: Mediasi Penal Dalam Sistem Peradilan Pidana Indonesia, hlm. 22-23

10 Inpres No. 8 Tahun 2002 tentang Pemberian Jaminan Kepastian Hukum Kepada Debitur yang Telah Menyelesaikan Kewajibannya atau Tindakan Hukum Kepada Debitur yang Tidak Menyelesaikan Kewajibannya Berdasarkan Penyelesaian Kewajiban Pemegang Saham. Kemudian Peraturan Kapolri No. Pol: B/3022/XII/2009/SDEOPS tanggal 14 Desember 2009 tentang Penanganan Kasus Melalui Alternatif Dispute Resulotion (ADR) serta Peraturan Kapolri Nomor 7 Tahun 2008 tentang Pedoman dasar Strategi dan Implementasi Pemolisian Masyarakat Dalam Penyelenggaraan Tugas Polri. Berikutnya Putusan Mahkamah Agung RI Nomor 1644 K/Pid/1988 tanggal 15 Mei 1991, Putusan Pengadilan Negeri Jakarta UtaraTimur Nomor 46/Pid/78/UT/WAN tanggal 17 Juni 1978 dalam kasus Ny. Ellya Dado dimana karena adanya penyelesaian secara "perdamaian", sehingga perbuatan diantara para pihak tidak merupakan suatu kejahatan atau pelanggaran yang dapat dihukum lagi. Kemudian praktik mediasi penal yang dilakukan dalam sidang Majelis Adat Dayak Nasional (MADN) pada masyarakat 
Banyak implikasi positif bila dilakukan implementasi mediasi penal sebagai perwujudan nilai-nilai Pancasila. Pertama, penumpukan perkara tidak terjadi di pengadilan, sehingga secara ekonomis pengeluaran keuangan dan perekonomian negara tidak terjadi dan mengurangi waktu yang diperlukan untuk menyelesaikan suatu perkara pidana. Korelasi dimensi ini, karena penumpukan perkara tidak terjadi maka lembaga pemasyarakatan relatif tidak overload. Kedua, dari perspektif korban karena membantu mengurangi rasa balas dendam terhadap pelaku, maka antar individu terjalin tali silaturahmi kembali. Pelaku meminta maaf dan korban telah memaafkan sehingga mengurangi rasa bersalah pelaku dan tercipta suasana rekonsiliasi yang merupakan pencerminan asas musyawarah mufakat, sehingga kehidupan berbangsa dan bernegara menjadi selaras, serasi dan seimbang. Kemudian juga tekanan terhadap korban menjadi relatif berkurang dibandingkan berperkara di pengadilan, oleh karena tidak perlu menjadi saksi, membawa saksi, menyewa pengacara, dan mendapat kesempatan untuk mengontrol hasilnya. Ketiga, dari perspektif pelaku tidak pidana akan terhindar dari pemidanaan, stigma atau catatan kejahatan yang telah diperbuat, didenda atau biaya perkara sebagai ganti kerugian, dan lain sebagainya. Keempat, merupakan media serta kesempatan antara korban dan pelaku bertemu membicarakan kejahatan yang dilakukan pelaku dan telah memberi stigma negatif dalam kehidupan korban, kemudian pula korban dapat mengungkapkan perhatian, keinginan dan perasaannya serta meminta restitusi. Kelima, dari perspektif normatif,

Kalimantan Tengah terhadap Tamrin Amal Tamagola pada tanggal 22 Januari 2011, serta diatur pula dalam ketentuan Pasal 145 ayat (1) huruf d RUU KUHP ditentukan bahwa, "kewenangan penuntutan gugur karena penyelesaian di luar proses". mediasi penal berasaskan nilai-nilai Pancasila dan keadilan restoratif, apabila diimplementasikan dalam kebijakan legislasi maka aturan hukum relatif dapat diterima masyarakat karena diambil, diangkat, diterapkan dan berorientasi dari kandungan nilai-nilai budaya yang lahir, hidup, tumbuh dan berkembang dalam masyarakat Indonesia. Keenam, dilakukannya mediasi penal penanganan perkara menjadi lebih fleksibel, proses lebih cepat, sederhana dan hemat biaya dibandingkan dengan prosedural panjang peradilan sesuai dengan sistem peradilan pidana yang berlaku selama ini.

Akan tetapi, apabila dimensi konteks tersebut tidak berhasil dikarenakan adanya paradigma masyarakat dan penegak hukum masih sangat legalistik sehingga kehendak menempuh mediasi penal tidak terwujud. Kemudian apabila pihak-pihak tidak berperan aktif menempuh prosedur mediasi penal maka penyelesaian perkara akan berakhir dengan penghukuman dan pemidanaan yang mengakibatkan lapas mengalami over capacity. Selanjutnya, apabila penerapan mediasi penal tidak berhasil maka penyelesaian perkara akan ditempuh melalui proses litigasi yang memakan waktu cukup lama. Akhirnya, apabila tujuan mediasi penal tidak tercapai maka proses pemidanaan berupa pidana penjara tidak mencapai keadilan restoratif sebagai perwujudan nilai-nilai Pancasila.

\section{B. Implementasi Mediasi Penal Sebagai Perwujudan Nilai-Nilai Pancasila Guna Mendukung Supremasi Hukum Dalam Rangka Pembangunan Nasional}

1. Mediasi Penal Sebagai Perwujudan Nilai-Nilai Saat Ini

Mediasi penal (penal mediation) sering juga disebut dengan berbagai istilah, antara lain: "mediation in criminal cases" atau "mediation in penal matters" yang dalam istilah Belanda disebut strafbemiddeling, dalam istilah Jerman disebut "Der 
Außergerichtliche Tatausgleich" (disingkat ATA) dan dalam istilah Perancis disebut "de mediation penale". Karena mediasi penal terutama mempertemukan antara pelaku tindak pidana dengan korban, maka mediasi penal ini sering juga dikenal dengan istilah Victim Offender Mediation (VOM), Tate Opfer Ausgleich (TOA), atau Offender Victim Arrangement (OVA). Mediasi penal merupakan salah satu bentuk alternatif penyelesaian sengketa di luar pengadilan (yang biasa dikenal dengan istilah ADR) atau "Alternative Dispute Resolution"; ada pula yang menyebutnya "Apropriate Dispute Resolution". ADR pada umumnya digunakan dilingkungan kasus-kasus perdata, tidak untuk kasus-kasus pidana. Berdasarkan perundang-undangan yang berlaku di Indonesia saat ini (hukum positif) pada prinsipnya kasus pidana tidak dapat diselesaikan di luar pengadilan, walaupun dalam hal-hal tertentu, dimungkinkan adanya penyelesaian kasus pidana di luar pengadilan. ${ }^{11}$

Pada dasarnya, mediasi penal merupakan salah satu bentuk alternatif penyelesaian sengketa/perkara di luar pengadilan yang lazim digunakan dalam lingkungan kasus-kasus perdata berdasarkan asas restorative justice. Akan tetapi, berdasarkan perundang-undangan yang berlaku di Indonesia saat ini (hukum positif) pada asasnya kasus pidana tidak dapat diselesaikan di luar pengadilan, walaupun dalam hal-hal tertentu, dimungkinkan adanya penyelesaian kasus pidana di luar pengadilan.

Pada hakikatnya, kondisi mediasi penal sebagai perwujudan nilai-nilai Pancasila saat ini dapat dideskripsikan sebagai berikut:

\section{a. Mediasi penal tidak diatur dalam undang-undang melainkan hanya diatur secara parsial dan terbatas berupa peraturan Kapolri/Menteri. Ditataran regulasi mediasi penal diatur dalam Surat Kapolri No Pol:}

11 Barda Nawawi Arief. 2008. Semarang: Mediasi Penal Penyelesaian..., Op.Cit., hlm. 1-2
B/3022/XII/2009/SDEOPS tanggal 14 Desember 2009 tentang Penanganan Kasus Melalui Alternatif Dispute Resolution (ADR) serta Peraturan Kepala Kepolisian Negara Republik Indonesia Nomor 7 Tahun 2008 Tentang Pedoman Dasar Strategi dan Implementasi Pemolisian Masyarakat Dalam Penyelenggaraan Tugas Polri. Pada dasarnya, peraturan tersebut mengatur tentang penanganan kasus pidana melalui ADR dengan sifat kerugian materi kecil, disepakati para pihak, dilakukan melalui prinsip musyawarah mufakat, harus menghormati norma sosial/ adat serta memenuhi asas keadilan dan apabila dicapai melalui ADR pelakunya tidak lagi disentuh oleh tindakan hukum lain. Kemudian dalam diktum pertama angka 4 Inpres No. 8 Tahun 2002 disebutkan bahwa, "dalam hal pemberian kepastian hukum sebagaimana dimaksud dalam angka $1^{12}$ menyangkut pembebasan debitur dari aspek pidana yang terkait langsung dengan program Penyelesaian Kewajiban Pemegang Saham, yang masih dalam tahap penyelidikan, penyidikan

12 Diktum pertama angka 1 Inpres Np. 8 Tahun 2002 berbunyi, "Kepada para Debitur yang telah menyelesaikan kewajiban Pemegang Saham, baik yang berbentuk MSAA, MRNIA, dan/atau Akta Pengakuan Utang/APU, diberikan bukti penyelesaian berupa pelepasan dan pembebasan dalam rangka jaminan kepastian hukum sebagaimana diatur dalam perjanjianperjanjian tersebut". Kemudian diktum pertama angka 3 Inpres No. 8 Tahun 2002 berbunyi, "Kepada para Debitur yang tidak menyelesaikan atau tidak bersedia menyelesaikan kewajibannya kepada Badan Penyehatan Perbankan Nasional baik dalam rangka MSAA, MRNIA, dan/atau Akta Pengakuan Utang/APU sampai dengan berakhirnya batas waktu yang telah ditetapkan oleh Komite Kebijakan Sektor Keuangan (KKSK), diambil tindakan hukum yang tegas dan konkret, yang dilaksanakan secara terkoordinasi antara Ketua Badan Penyehatan Perbankan Nasional, Kepala Kepolisian Negara Republik Indonesia dan Jaksa Agung Republik Indonesia". 
dan/atau penuntutan oleh instansi penegak hukum, maka sekaligus juga dilakukan dengan proses penghentian penanganan aspek pidananya, yang pelaksanaannya tetap dilakukan sesuai dengan ketentuan peraturan perundangundangan yang berlaku". Konsekuensi logisnya dalam praktik peradilan, sering kasus pidana diselesaikan di luar pengadilan melalui berbagai diskresi aparat penegak hukum (kepolisian/kejaksaan). Praktik penyelesaian demikian sering terjadi suatu kasus secara informal telah ada penyelesaian damai namun tetap saja diproses ke pengadilan sesuai hukum yang berlaku, karena mediasi penal secara nasional tidak ada aturan hukumnya.

b. Mediasi Penal dalam praktik di daerah tertentu dilakukan melalui mekanismemusyawarah/pemaafan yang ada di dalam masyarakat melalui kepala adat seperti dalam bentuk musyawarah keluarga, musyawarah desa, masyawarah adat dan juga melalui peradilan adat di samping sistem peradilan pidana.

Pada masyarakat Nanggroe Aceh Darussalam sebagaimana UU Nomor 11 Tahun 2006 tentang Pemerintahan Aceh diterapkan dan dikenal penyelesaian perkara dilakukan terlebih dahulu melalui Peradilan Gampong atau Peradilan Damai. ${ }^{13}$

13 Berdasarkan UU Nomor 11 Tahun 2006 maka di Aceh penjabarannya dibuat ketentuan perundangan-undangan dalam bentuk Qanun yang berhubungan dengan hukum adat seperti Qanun Aceh Nomor 9 Tahun 2008 tentang Pembinaan Kehidupan Adat dan Adat Istiadat, Qanun Aceh Nomor 10 Tahun 2008 tentang Lembaga Adat. Kemudian selain dibuat Qanun Aceh (Qanun tingkat Propinsi) terdapat juga Qanun-Qanun tingkat Kabupaten/ Kota antara lain di dalam Qanun Kabupaten Aceh Tengah Nomor 10 Tahun 2002 tentang Hukum Adat Gayo. Di Aceh, pengadilan adat yang dikenal dengan istilah Pengadilan Gampong atau Pengadilan Damai juga diimplementasikan dalam Keputusan Bersama seperti di Kabupaten Aceh Tengah adanya Keputusan Bersama antara Bupati, Ketua DPRK dan Ketua MAA
Selain itu, dalam Qanun Aceh Nomor 9 Tahun 2008 tanggal 30 Desember 2008 tentang Pembinaan Kehidupan Adat dan Adat Istiadat khususnya Pasal 13 menentukan, "penyelesaian sengketa/perselisihan adat dan adat istiadat diselesaikan secara bertahap", kemudian disebutkan pula, bahwa "aparat penegak hukum memberikan kesempatan agar sengketa/perselisihan diselesaikan terlebih dahulu secara adat atau nama lain" dan, "apabila para pihak tidak puas terhadap putusan adat dapat mengajukan perkaranya ke aparat penegak hukum dan keputusan adat dapat dijadikan pertimbangan oleh aparat penegak hukum". Begitu pula dalam masyarakat Bali, dikenal lembaga adat berupa banjar, subak, desa pakraman, majelis desa pakraman, dan lain sebagainya yang berperan menyelesaikan perkara adat. Apabila terjadi perkara, penyelesaiannya dilakukan secara berjenjang. Mulai dari penyelesaian ditingkat intern keluarga, selanjutnya ketingkat banjar, bila gagal ketingkat bendesa adat (desa pakraman). Kemudian, bila tidak berhasil berlanjut ketingkat majelis desa pakraman melalui mediasi (majelis alit desa pakraman), berikutnya ketingkat sabha kertha (peradilan adat oleh majelis madya desa pakraman) dan tingkat bandingnya oleh majelis utama desa pakraman. Pada desa adat pakraman diterapkan adanya awig-awig yang merupakan dimensi lain identik dengan penyelesaian perkara di luar pengadilan melalui mediasi penal. Misalnya, dalam Pasal (Pawos) 66 awig-awig desa pakraman tanah Aron Kabupaten Karangasem disebutkan bahwa, "yang berwenang menyelesaikan

Kabupaten Aceh Tengah No. 373 Tahun 2008, No 320/ DPRK/2008, No.Pol B/810/2008 Res Aceh Tengah dan No. 110/MAA/V/2008. 
perkara di desa adalah prajuru desa sebagai hakim peradilan desa adalah kelihan banjar, kalau yang berperkara berasal dari satu banjar dan bendesa kalau yang berperkara semuanya berasal dari satu desa" (Sane wenang mawosin mekadi mutusang wicara ring desa inggih punika prajuru desa sinaggeh kerta desa; ha. Kelihan banjar, pradene sang mewicara sane patunggalan banjar; na. Bendesa, sang mewicara sami-sami ring petunggalan desa adat). Kemudian di Nusa Tenggara Barat (Lombok), khususnya pada masyarakat suku Sasak dikenal cara penyelesaian masalah (perkara) melalui musyawarah (Begundem) untuk mencapai perdamaian. Dalam Kotaragama, angka 49 huruf b tentang Kebidjaksanaan atau Kedermawanan Radja, ditentukan bahwa:

"Ini tjara orang tjerdik pandai berbitjara. Dalam membitjarakan sesuatu masalah oleh diantara warga desa (Negara), djika tidak ada pendahuluan nasehat mengakibatkan tidak baik, akan tetapi bila masalah diselesaikan melalui perdamaian, kedua belah fihak akan merasakan manfaatnja. Tjara inilah jang dikehendaki/diterima baik oleh Radja karena memang tjara demikian itu mendjadi ketentuan jang dinamakan keadilan" 14

Berdasarkan ketentuan konteks di atas maka Suku Sasak dalam menyelesaikan perselisihan pertama-tama hendaklah didahului dengan memberikan peringatan atau nasihat, dan jika peringatan tidak diindahkan maka diselesaikan melalui musyawarah untuk

14 H. Lalu Parman. 2011. Mataram: Mediasi Penal Dalam Sistem Peradilan Pidana Indonesia, hIm. 4 mencapai perdamaian. Musyawarah (Begundem) dilaksanakan oleh lembaga Adat yang disebut Krama Adat sesuai tingkat dan kompetensinya. Untuk tingkat lingkungan atau Dusun (Gubuk) dilaksanakan oleh Krama Gubuk yang berwenang menyelesaikan masalah antar warga lingkungan atau antar keluarga di lingkungan tersebut. Krama Gubuk terdiri dari Kepala Lingkungan (kelian) selaku ketua adat di lingkungan, tokoh agama (kiai gubuq) dan pemukapemuka masyarakat. Sedangkan di tingkat desa dilaksanakan oleh Krama Desa yang terdiri dari Kepala Desa selaku Kepala Adat, Juru Tulis, Penghulu Desa, Pemuka Masyarakat dan Para Kelian. Kemudian mediasi penal dilakukan dalam bentuk peradilan adat. Misalnya, Sidang Adat terhadap Prof. Dr. Thamrin Amal Tomagola, seorang sosiolog ketika menjadi saksi ahli dalam suatu persidangan di Pengadilan Negeri Bandung dengan merujuk pada hasil penelitiannya menyatakan bahwa hubungan seksual sebelum menikah biasa dikalangan masyarakat Dayak. Pernyataan tersebut membuat masyarakat Dayak tersinggung. Di Palangkaraya lebih dari 1000 warga Dayak menggelar aksi damai memprotes keras pernyataan Tamrin Amal Tomagola. Aksi warga Dayak di Bundaran Kota Palangkaraya diwarnai pembacaan pernyataan sikap Majelis Adat Dayak Nasional (MADN) yang ditandatangani Presiden MADN. Kemudian MADN mengganggap penyataan Tamrin melukai perasaan, harkat, dan martabat masyarakat Dayak. Pernyataan itu juga melecehkan adat istiadat suku Dayak yang mengkedepankan prinsip belom bahadat (hidup bertata krama dan beradat dalam berbagai segi kehidupan). 
Kemudian MADN meminta Tamrin mempertanggungjawabkan apa yang telah dilontarkan di depan hukum positif, dan tuntutan hukum adat Dayak untuk menghindari terjadinya disharmoni dan konflik harizontal yang dapat merusak kehidupan masyarakat MADN juga minta Tamrin meminta maaf kepada seluruh masyarakat Dayak secara terbuka melalui media cetak dan elektronik. Terhadap pernyataan tersebut, maka Tamrin kemudian disidang adat di Palangkaraya. Persidangan adat tersebut dilakukan oleh MADN yang diberi nama Persidangan Dayak Maniring Tuntang Menetes Hinting Bunu yang berlangsung di Ruang Betang Tingang Ngaderang (Betang Mandala Wisata) Palangkaraya, Kalimantan Tengah antara masyarakat Dayak dengan Tamrin sebagai bentuk melindungi harkat dan martabat penegakan hukum adat Dayak terhadap delegitimasi, demoralisasi, penistaan maupun penghinaan terhadap masyarakat Dayak. Selain itu pula, asasnya pernyataan Tamrin tersebut tidak sesuai dengan pandangan masyarakat Dayak yang mengganggap hubungan seksual tanpa ikatan perkawinan sebagai hal biasa, dianggap melukai perasaan, merendahkan harkat dan martabat serta pelecehan terhadap adat istiadat suku Dayak. Dalam sidang tersebut Tamrin Amal Tomagola dinyatakan bersalah dalam sidang adat suku Dayak. Sidang yang dipimpin oleh tujuh tokoh adat Dayak itu memerintahkan Tamrin untuk mencabut pernyataannya yang menyebutkan bahwa warga Dayak biasa melakukan hubungan suami istri di luar ikatan perkawinan. Terhadap hal ini Tamrin yang hadir disidang tersebut bersedia menerima dan menyanggupi semua putusan majelis sidang adat dan mencabut pernyataannya dan meminta maaf kepada seluruh masyarakat Dayak di depan sidang. Kemudian, dalam sidang adat tersebut Tamrin juga harus membayar denda acara adat senilai Rp. 77.777.777 yang akan digunakan untuk acara adat dan juga harus mencabut hasil penelitian yang menyangkut hal tersebut. Lewat sidang adat yang disaksikan langsung oleh Presiden Majelis Adat Dayak Nasional (MADN), para tokoh adat se-Kalimantan, unsur Muspida Kalteng dan ratusan masyarakat yang menjadi saksi sidang diberi nama Persidangan Adat Dayak Maniring Tuntang Manetes Hinting Bunu antara masyarakat Dayak dan Tamrin Amal Tamagola itu secara harfiah berarti memutus dendam yang berkepanjangan dalam menuju perdamaian kearah yang lebih baik antara kedua belah pihak. Sidang itu pertama kali dilakukan dan bersifat final serta mengikat. Persidangan adat tersebut bertujuan mencapai kedamaian, rekonsiliasi, kekeluargaan, serta tetap mempertahankan harkat serta martabat suku Dayak secara keseluruhan. Tuntutan terhadap Tamrin itu berdasarkan kesepakatan Tumbang Anoi 1894.

\section{c. Mediasi penal juga terlaksana dan diakui melalui yurisprudensi Mahkamah Agung RI dan lewat Putusan Pengadilan Negeri.} Misalnya, sebagai salah satu contohnya pada Putusan Mahkamah Agung RI Nomor 1644 K/Pid/1988 tanggal 15 Mei 1991 dimana dalam ratio decidendi putusan disebutkan bahwa apabila seseorang melanggar hukum adat kemudian Kepala dan Para Pemuka Adat memberikan reaksi adat (sanksi/obat adat) maka yang bersangkutan tidak dapat 
diajukan lagi (untuk kedua kalinya) sebagai terdakwa dalam persidangan Badan Peradilan Negara (Pengadilan Negeri) dengan dakwaan yang sama melanggar hukum ada dan dijatuhkan pidana penjara menurut ketentuan KUH Pidana (Pasal 5 ayat (3) sub b UU drt Nomor 1 Tahun 1951) sehingga dalam keadaan demikian pelimpahan berkas perkara serta tuntutan Kejaksaan di Pengadilan Negeri harus dinyatakan tidak dapat diterima (niet ontvankelijk Verklaard). Konklusi dasar dari yurisprudensi tersebut mengakui eksistensi peradilan adat dimana adanya mediasi penal antara pelaku dengan korban, kemudian penjatuhan "sanksi/obat adat" tersebut dilakukan sebagai suatu pemulihan keseimbangan antara pelaku dengan masyarakat adatnya sehingga adanya keseimbangan antara alam kosmis dan non kosmis menjadi kembali seperti sedia kala. Kemudian dalam Putusan Pengadilan Negeri Jakarta Utara-Timur Nomor: 46/Pid/78/UT/WAN tanggal 17 Juni 1978 dimana dalam perkara Ny. Ellya Dado, lazim disingkat sebagai "Kasus Ny. Elda", adanya penyelesaian secara "perdamaian" maka perbuatan diantara para pihak tidak merupakan suatu kejahatan atau pelanggaran yang dapat dihukum lagi, dan oleh karenanya melepaskan tertuduh dari segala tuntutan hukum. Dalam dimensi lain, ternyata pada saat kini ratio decidendi putusan tersebut juga dipergunakan oleh Mahkamah Agung RI dalam mengadili perkara pada tingkat Peninjauan Kembali Nomor 107 PK/Pid/2006 tanggal 21 November 2007.

\section{Mediasi Penal Sebagai Perwujudan Nilai-Nilai uang Diharapkan}

Sejak dahulu pola penyelesaian sengketa/perkara pada masyarakat
Indonesia dilakukan berdasarkan musyawarah mufakat, misalnya dalam bentuk rembuk desa, kerapatan adat, peradilan adat, peradilan gampong, budaya bakar batu, lembaga begundem dan lain sebagainya. Oleh karena itu, dengan tolok ukur demikian sebaiknya masyarakat lebih memilih perdamaian dalam penyelesaian perkara/sengketa. Jalur musyawarah merupakan jalur utama yang digunakan masyarakat hukum adat dalam menyelesaikan perkara/sengketa, karena dalam musyawarah akan dapat dibuat kesepakatan damai yang menguntungkan kedua belah pihak.

Hukum adat berakar dan digali dari kebudayaan tradisional, hidup, tumbuh dan berkembang, sebagai penjelmaan perasaan hukum yang nyata dari rakyat. Hukum adat sebagai hukum asli menjadi identitas bangsa Indonesia, mempunyai nilai luhur untuk tetap dipertahankan seiring perkembangan zaman dan peradaban. Hakikat dan substansi hukum adat mengutamakan jalan penyelesaian secara rukun dan damai melalui musyawarah mufakat dalam menyelesaikan perselisihan diantara warga masyarakat. Para pihak saling memaafkan dan tidak terburu-buru membawa perkara ke peradilan, sehingga tetap terjaga hubungan baik, harmonisasi, keselarasan dan keserasian diantara para pihak, karena pada hakikatnya neraca keseimbangan dalam masyarakat yang terganggu akibat terjadinya sengketa atau perselisihan dapat dipulihkan seperti keadaan semula.

Konsep tersebut bermakna berperkara diperadilan sejauh mungkin harus dihindari. Sekalipun tidak bisa dihindari, maka perselisihan, persengketaan, pertentangan, atau perbedaan paham atau sejenisnya sebaiknya diselesaikan secara musyawarah. Peradilan sebagai lembaga litigasi menjadi pilihan terakhir bila penyelesaian sengketa tidak dapat diselesaikan secara musyawarah mufakat. Dapat ditegaskan bahwa pendekatan kompromis atau musyawarah mufakat 
bertujuan untuk mencari titik temu diantara berbagai kepentingan yang berbeda sampai dihasilkan suatu kesepakatan. Proses ini disamping menghemat waktu peyelesaian perkara namun juga dilakukan dengan cara sederhana dan biaya ringan.

Musyawarah merupakan bentuk nilai-nilai kebiasaan yang hidup dalam masyarakat Indonesia, oleh karenanya tidaklah heran apabila pendiri negara Indonesia memasukkan musyawarah sebagai bagian dari nilai-nilai luhur Pancasila sebagai dasar negara. Pancasila merupakan cermin dari kebiasaan-kebiasaan yang ada di masyarakat, kemudian dituangkan dalam suatu bentuk dasar negara. Demikian juga halnya kebiasaan masyarakat Indonesia dari berbagai suku, musyawarah tampaknya menjadi jalan bagi penyelesaian segala sengketa diantara mereka.

Konteks korelasi implementasi mediasi penal sebagai perwujudan nilai-nilai Pancasila yang diharapkan, berbagai dampak positif mediasi penal harus dapat dijadikan kekuatan guna mendukung supremasi hukum dalam rangka pembangunan nasional. Hal ini sesuai landasan pemikiran dengan pisau analisis landasan teori mediasi penal, teori keadilan restoratif dan teori hukum pembangunan.

Teori mediasi penal dengan 6 (enam) model penyelesaian, merupakan dimensi yang dapat dijadikan arah, pegangan dan petunjuk bagaimana seharusnya mediasi penal akan dilakukan sehingga sesuai dengan kultur masyarakat Indonesia. Pada teori keadilan, dilakukan mediasi penal mengandung asas diterapkannya solusi "menang-menang" (win-win) dan bukan berakhir dengan situasi "kalahkalah" (lost-lost) atau "menang-kalah" (win-lost). Pada proses mediasi penal diperoleh puncak keadilan tertinggi karena terjadi kesepakatan para pihak yang terlibat dalam perkara pidana yaitu antara pihak pelaku, korban, dan/atau keluarga pelaku dan korban sehingga terjalinnya silaturahmi, diterapkannya restorative justice, sehingga dihindari adanya penghukuman sebagai bentuk asas retributif. Kemudian, teori hukum pembangunan yang dilaksanakan melalui pembaruan hukum dengan tetap memperhatikan kemajemukan tatanan hukum yang berlaku dan pengaruh globalisasi. Dalam konteks upaya meningkatkan kepastian, perlindungan, kesadaran dan penegakan hukum, hakhak asasi manusia, serta pelayanan hukum berintikan keadilan, kebenaran, ketertiban dan kesejahteraan dalam rangka penyelenggaraan negara yang makin tertib dan teratur, sehingga penyelenggaraan pembangunan nasional akan semakin meningkat.

Oleh karena itu, tolok ukur implikasi positif mediasi penal sebagai kekuatan diharapkan dapat mendorong upaya pengentasan berbagai pokok persoalan yang telah diindentifikasikan. Dengan demikian, kondisi implementasi mediasi penal sebagai perwujudan nilai-nilai Pancasila guna mendukung supremasi hukum dalam rangka pembangunan nasional diharapkan dapat benar-benar diwujudkan. Kondisi yang diharapkan tersebut dapat diuraikan sebagai berikut:

(a) Dalam tataran instrumental mediasi penal sebagai perwujudan nilainilai Pancasila diharapkan dapat dijabarkan dalam bentuk undangundang

Implementasi mediasi penal sebagai perwujudan nilai-nilai Pancasila mempunyai beberapa implikasi positif. Oleh karena itu, sangat diperlukan adanya undangundang mediasi penal. Pada undangundang ini hendaknya diatur tentang mediasi penal yang dilakukan ditingkat penyidikan, penuntutan, pengadilan dan lembaga pemasyarakatan. Selain itu, juga diatur tentang eksistensi lembaga baru, petugas mediator, proses dan substansi mediasi penal.

Misalnya, mekanisme mediasi penal pada tingkat penyidikan, antara pelaku dan korban, masuk dalam 
sistem peradilan pidana. Pihak kepolisian melakukan proses mediasi penal. Apabila mediasi penal berhasil, maka dibuat perdamaian, yang dapat berupa pemberian ganti rugi, rekonsiliasi, perkaranya tidak sampai ke pengadilan, atau dicabut. Apabila, mediasi penal yang dilakukan gagal, maka kembali ke dalam sistem peradilan pidana, sebagaimana dapat dilihat dalam bagan 2 berikut ini. ${ }^{15}$

\section{Bagan 2 \\ Mediasi Penal Oleh Kepolisian}

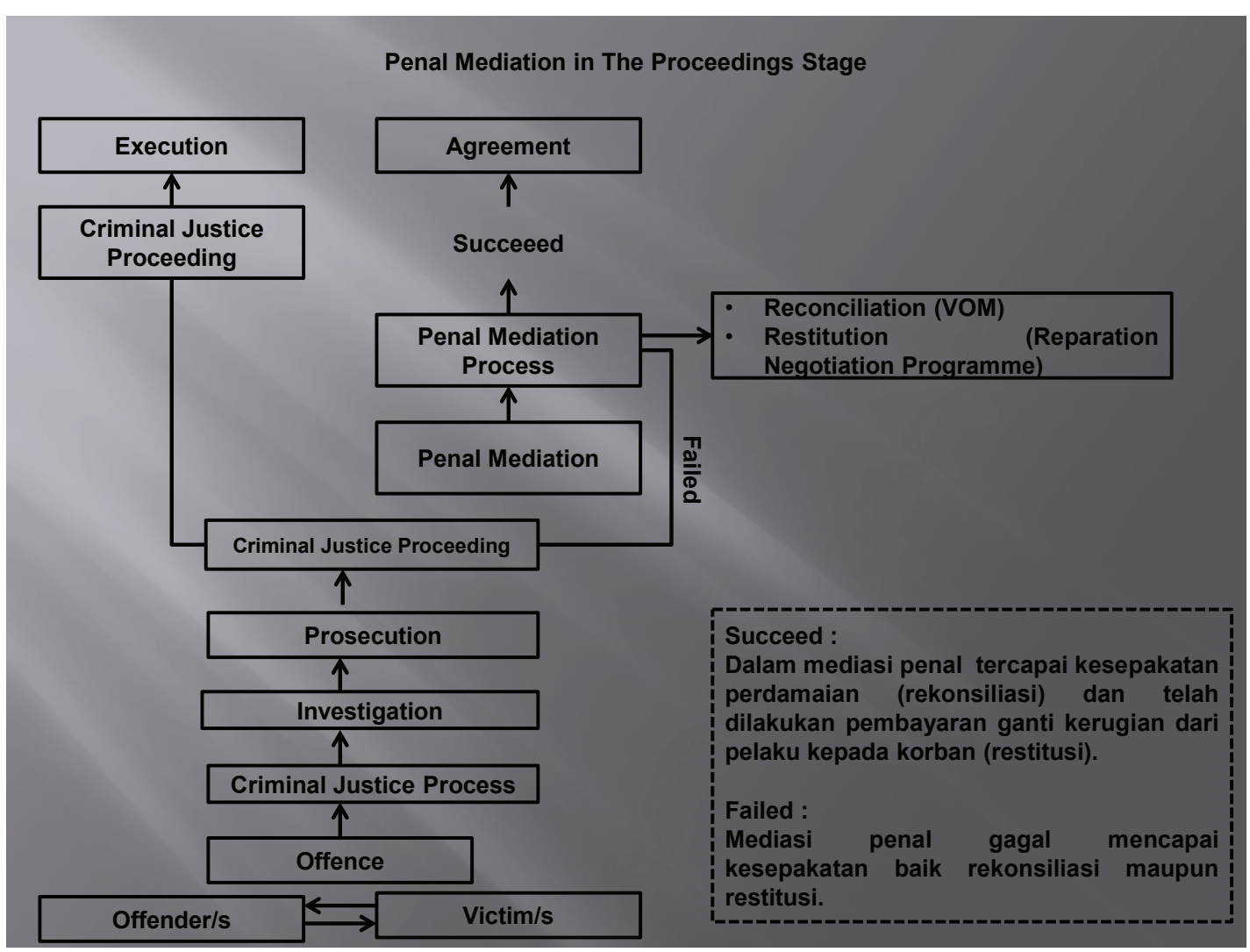

Kemudian, ada kalanya ditingkat penyidikan mediasi penal gagal dilakukan, akan tetapi tidak tertutup kemungkinan ditingkat penuntutan oleh Kejaksaan berhasil dilakukan. Apabila berhasil, maka perkara tidak masuk ke dalam sistem peradilan pidana, dan berujung pada perdamaian yang dapat berupa pemberian ganti rugi, rekonsiliasi, perkaranya tidak sampai ke pengadilan, atau dicabut. Apabila, mediasi penal gagal, maka kembali masuk ke dalam sistem peradilan pidana, sebagaimana dapat dilihat dalam bagan 3 berikut ini. ${ }^{16}$

\footnotetext{
15 Umi Rozah. 2012 :"Konstruksi Politik Hukum Mediasi Penal Sebagai Alternatif Penyelesaian Perkara Pidana": Hukum Pidana Dalam Perspektif , hlm. 326

$16 \quad$ Umi Rozah. 2012 :"Konstruksi Politik Hukum...", Ibid., hIm. 328
} 


\section{Bagan 3 \\ Mediasi Penal Oleh Kejaksaan}

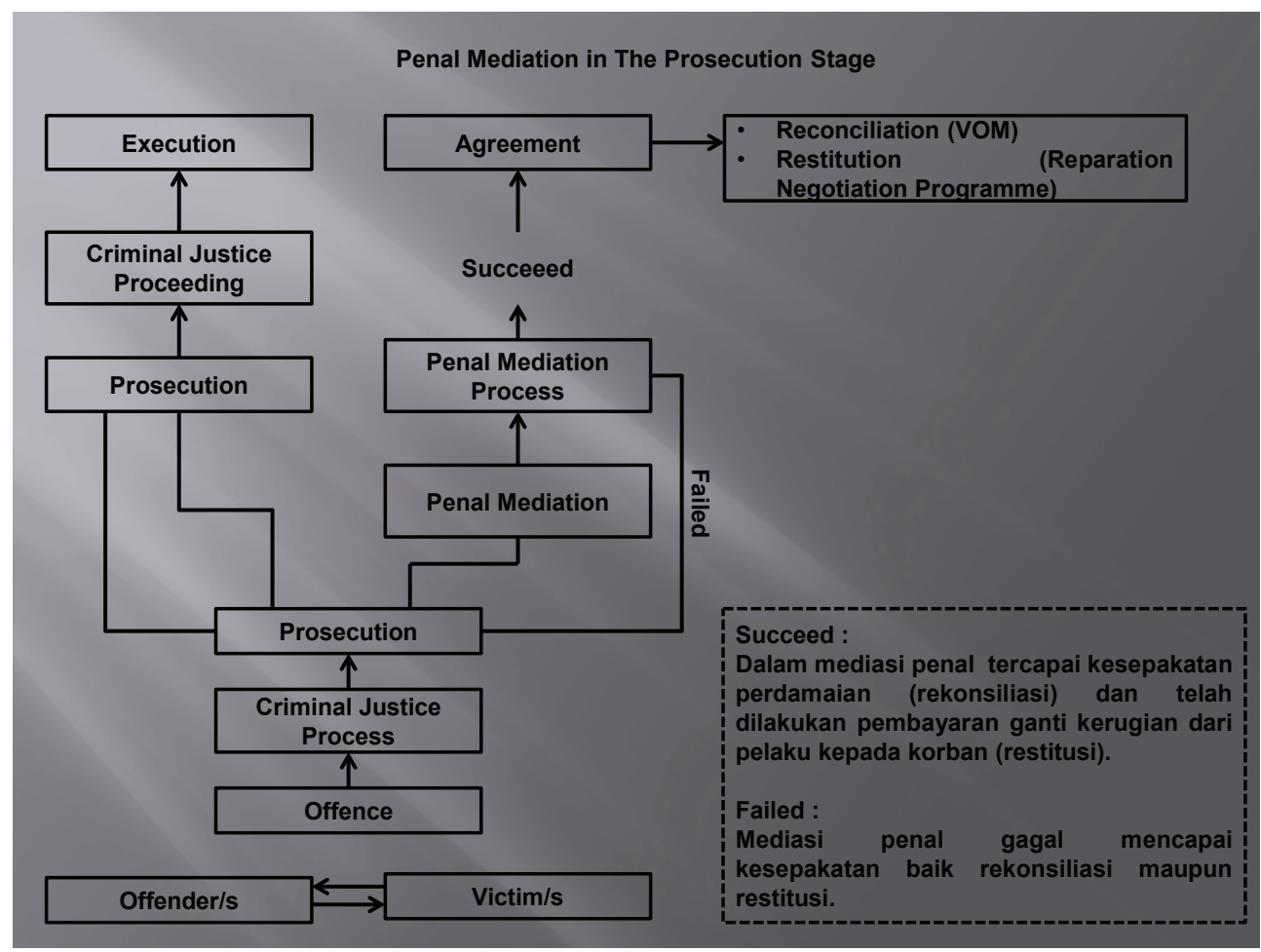

Begitu pula halnya di Pengadilan. Apabila di Kejaksaan mediasi penal gagal dilakukan tidak tertutup akan berhasil ataupun juga tetap gagal dilakukan di pengadilan sebagaimana dapat dilihat dalam bagan 4 berikut ini. ${ }^{17}$

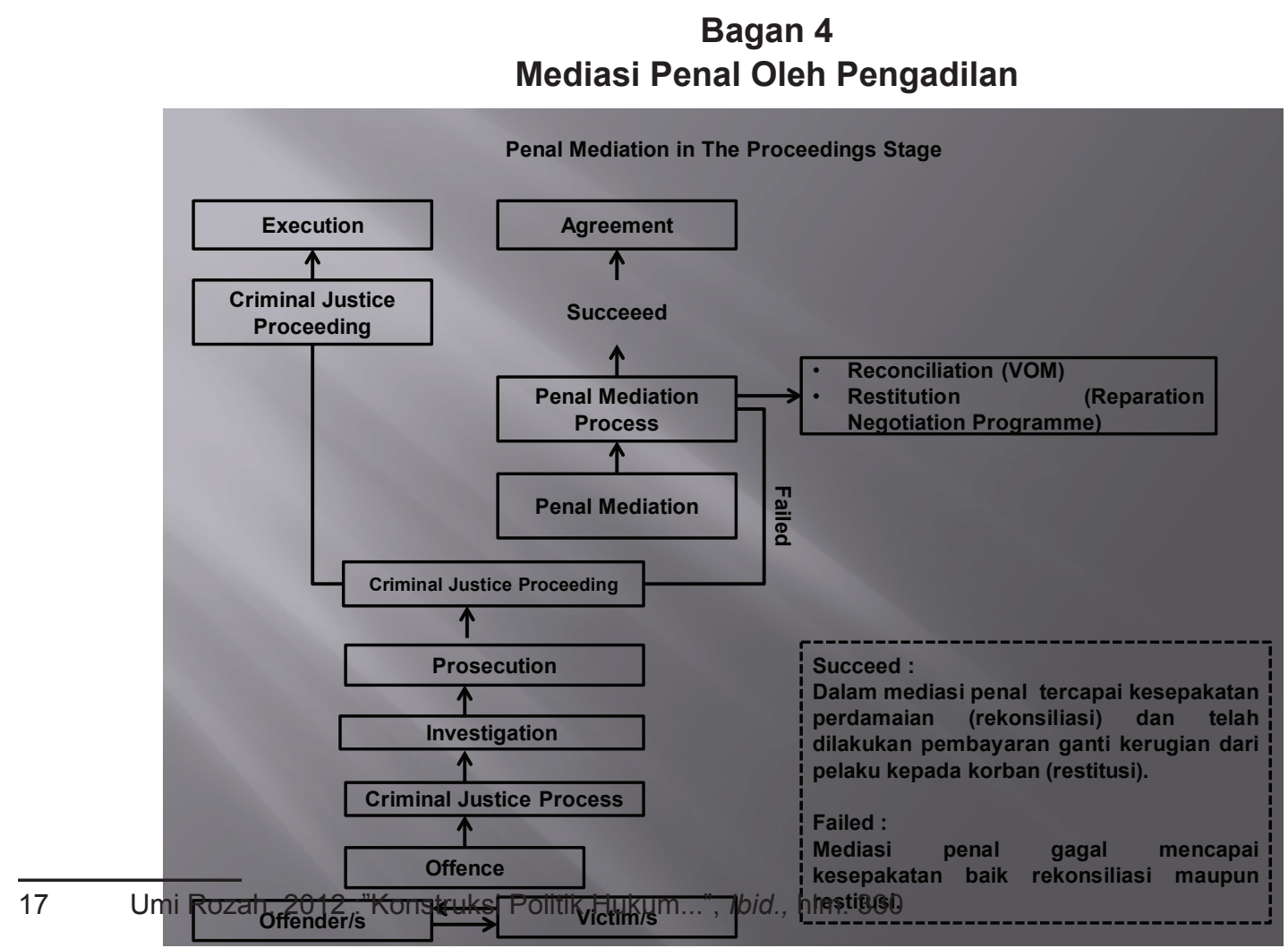


(b) Pada tataran praktik/praktis hendaknya peradilan adat diatur sebagai salah satu cara atau solusi untuk melakukan mediasi penal sehingga membudayanya kearifan lokal di samping sistem peradilan pidana

Kearifan lokal hukum adat (local wisdom) merupakan nilai-nilai yang hidup dalam masyarakat (inner order/living law) Indonesia. Dari dimensi ini, mediasi penal dalam praktik dilakukan melalui mekanisme musyawarah lewat lembaga adat yang diatur dalam bentuk awig-awig. Misalnya, di Bali dikenal lembaga adat berupa banjar, subak, desa pakraman, majelis desa pakraman, yang berperan menyelesaikan perkara adat. Apabila terjadi perkara, penyelesaiannya dilakukan secara berjenjang. Mulai dari penyelesaian ditingkat intern keluarga, selanjutnya ketingkat banjar, bila gagal ketingkat bendesa adat (desa pakraman). Kemudian, bila tidak berhasil berlanjut ketingkat majelis desa pakraman melalui mediasi (majelis alit desa pakraman), berikutnya ketingkat sabha kertha (peradilan adat oleh majelis madya desa pakraman) dan tingkat bandingnya oleh majelis utama desa pakraman. Kemudian suku Sasak di Lombok dalam menyelesaikan perselisihan pertama-tama hendaklah didahului dengan memberikan peringatan atau nasihat, dan jika peringatan tidak diindahkan maka diselesaikan melalui musyawarah untuk mencapai perdamaian. Musyawarah (Begundem) dilaksanakan oleh lembaga Adat yang disebut Krama Adat sesuai tingkat dan kompetensinya. Untuk tingkat lingkungan atau Dusun (Gubuk) dilaksanakan oleh Krama Gubuk yang berwenang menyelesaikan masalah antar warga lingkungan atau antar keluarga di lingkungan tersebut. Karma Gubuk terdiri dari
Kepala Lingkungan (kelian) selaku ketua adat di lingkungan, tokoh agama (kiai gubuq) dan pemuka-pemuka masyarakat. Sedangkan di tingkat desa dilaksanakan oleh Krama Desa yang terdiri dari Kepala Desa selaku Kepala Adat, Juru Tulis, Penghulu Desa, Pemuka Masyarakat dan Para Kelian.

Di samping itu, mediasi penal juga ada dilakukan dalam bentuk peradilan adat. Misalnya, peradilan adat terhadap Prof. Dr. Thamrin Amal Tomagola, yang dilakukan oleh Majelis Adat Dayak Nasional (MADN) yang diberi nama Persidangan Dayak Maniring Tuntang Menetes Hinting Buni yang berlangsung di Ruang Betang Tingang Ngaderang (Betang Mandala Wisat) Palangkaraya, Kalimantan Tengah. Hasil sidang berakhir damai dimana Tamrin diwajibkan membayar denda acara adat senilai Rp. 77.777.777. Persidangan adat tersebut bertujuan mencapai kedamaian, rekonsiliasi, kekeluargaan, serta tetap mempertahankan harkat srta martabat suku Dayak secara keseluruhan. Tuntutan terhadap Tamrin itu berdasarkan kesepakatan Tumbang Anoi 1894.

Kemudian, sidang adat juga dikenal di Aceh. Pada masyarakat Nanggroe Aceh Darussalam sebagaimana UU Nomor 11 Tahun 2006 tentang Pemerintahan Aceh diterapkan dan dikenal untuk penyelesaian perkara dilakukan terlebih dahulu melalui Peradilan Gampong atau Peradilan Damai. Selain itu, dalam Qanun Aceh Nomor 9 Tahun 2008 tanggal 30 Desember 2008 tentang Pembinaan Kehidupan Adat dan Adat istiadat khususnya dalam Pasal 13 menentukan bahwa, "penyelesaian sengketa/perselisihan adat dan adat istiadat diselesaikan secara bertahap", kemudian disebutkan pula, bahwa "aparat penegak hukum 
memberikan kesempatan agar sengketa/perselisihan diselesaikan terlebih dahulu secara adat atau nama lain" dan, "apabila para pihak tidak puas terhadap putusan adat dapat mengajukan perkaranya ke aparat penegak hukum dan keputusan adat dapat dijadikan pertimbangan oleh aparat penegak hukum".

Selain itu, Mediasi penal juga terlaksana dan diakui melalui yurisprudensi Mahkamah Agung RI. Misalnya, sebagai salah satu contohnya pada Putusan Mahkamah Agung RI Nomor 1644 K/Pid/1988 tanggal 15 Mei 1991 dimana dalam ratio decidendi putusan disebutkan bahwa apabila seseorang melanggar hukum adat kemudian Kepala dan Para Pemuka Adat memberikan reaksi adat (sanksi/obat adat) maka yang bersangkutan tidak dapat diajukan lagi (untuk kedua kalinya) sebagai terdakwa dalam persidangan Badan Peradilan Negara (Pengadilan Negeri) dengan dakwaan yang sama melanggar hukum adat dan dijatuhkan pidana penjara menurut ketentuan KUH Pidana (Pasal 5 ayat (3) sub b UU drt Nomor 1 Tahun 1951) sehingga dalam keadaan demikian pelimpahan berkas perkara serta tuntutan Kejaksaan di Pengadilan Negeri harus dinyatakan tidak dapat diterima (niet ontvankelijk verklaard). Konklusi dasar dari yurisprudensi tersebut mengakui eksistensi peradilan adat dimana adanya mediasi penal antara pelaku dengan korban, kemudian penjatuhan "sanksi/obat adat" tersebut dilakukan sebagai suatu pemulihan keseimbangan antara pelaku dengan masyarakat adatnya sehingga timbul keseimbangan, keselarasan serta harmonisasi antara alam kosmis dan non kosmis menjadi kembali seperti sedia kala. Kemudian dalam Putusan Pengadilan Negeri Jakarta Utara-Timur Nomor: 46/Pid/78/UT/WAN tanggal 17 Juni 1978 dimana dalam perkara $N y$.
Ellya Dado, lazim disingkat sebagai "Kasus Ny. Elda", adanya penyelesaian secara "perdamaian" maka perbuatan diantara para pihak tidak merupakan suatu kejahatan atau pelanggaran yang dapat dihukum lagi, dan oleh karenanya melepaskan tertuduh dari segala tuntutan hukum. Dalam dimensi lain, ternyata pada saat kini ratio decidendi putusan tersebut juga dipergunakan oleh Mahkamah Agung RI dalam mengadili perkara pada tingkat Peninjauan Kembali Nomor 107 PK/Pid/2006 tanggal 21 November 2007.

Konklusi konteks di atas, dapat ditarik benang merah bahwa eksistensi peradilan adat diakui di Indonesia. Dalam tataran global dan regional, penyelesaian perkara pidana oleh peradilan/lembaga adat juga diakui di beberapa negara. ${ }^{18}$ Pada Negara Amerika Serikat, dipergunakan oleh lembaga adat suku Indian Comanche penyelesaian perkara pidana dengan mempergunakan 4 (empat) bentuk model yaitu penyelesaian antar pribadi (negoisasi), melalui perantara perempuan (negoisasi dengan bantuan pihak ketiga), bantuan kelompok (mediasi, negoisasi pihak ketiga) dan bantuan Panglima Perang (mediasi). Kemudian tindak pidana yang diselesaikan berupa perzinahan dan KDRT, serta pihak yang terlibat adalah pelaku, korban dan masyarakat. Pada Negara Bangladesh dipergunakan oleh lembaga adat Shalish (dapat dibedakan berupa shalish tradisional, shalish pemerintahan dan shalish NGO), penyelesaian perkara pidana mempergunakan 3 (tiga) model yaitu penyelesaian melalui mediasi penal, community based, mekanisme campuran antara mediasi penal

$18 \quad$ Vide lebih detail dalam: I Made Agus Mahendra Iswara. 2013. Jakarta: Mediasi Penal Penerapan NilaiNilai Restorative Justice Dalam Penyelesaian Tindak Pidana Adat Bali, Tesis, hlm. 84 
dengan community based. Kemudian tindak pidana yang diselesaikan berupa persoalan gender (kekerasan terhadap perempuan), Kekerasan Dalam Rumah Tangga (KDRT), perzinahan, poligami, perceraian, eksploitasi ekonomi terhadap anak dan perempuan serta pihak yang terlibat untuk menyelesaikan adalah pelaku, korban, masyarakat dan institusi lainnya.

Berikutnya, pada Negara Filipina dipergunakan oleh lembaga adat Barangays masyarakat adat Ifugao (Filipina Utara), penyelesaian perkara pidana mengutamakan mediasi. Kemudian tindak pidana yang diselesaikan berupa perselisihan antar anggota Barangays, perkara-perkara yang hukumannya tidak melebihi 1 (satu) tahun dan denda 5000 peso atau 60 pound serta pihak yang terlibat untuk menyelesaikannya adalah pelaku, korban, dan masyarakat.

Kemudian di Negara Liberia Tengah pada lembaga adat masyarakat Kpelle bentuk penyelesaian perkara pidana mengutamakan mediasi. Kemudian tindak pidana yang diselesaikan berupa perselisihan warisan dan KDRT serta pihak yang terlibat menyelesaikan adalah pelaku, korban dan masyarakat.

Selanjutnya pada Negara Malaysia dipergunakan oleh lembaga adat masyarakat Adat Iban maka model penyelesaian perkara pidana meliputi 4 (empat) bentuk yaitu mediasi, melalui upacara Bechara, melalui pengadilan penghulu (seperti banding) dan secara bertempoh (berkelahi). Kemudian tindak pidana yang diselesaikan berupa KDRT serta pihak yang terlibat menyelesaikan adalah pelaku, korban dan masyarakat.

Pada Negara Mexico khususnya lembaga adat masyarakat Adat Zapotec dan Peradilan kota berupa presidente, alcado dan sindico maka model penyelesaian perkara pidana diawali negoisasi personal, keluarga, mediasi, baru oleh Peradilan kota berupa presidente, alcado dan sindico. Kemudian tindak pidana yang diselesaikan berupa KDRT, perselisihan ekonomi, pengembangan tugas warga kota dan mengganggu ketertiban masyarakat serta pihak yang terlibat menyelesaikan adalah pelaku, korban, masyarakat, dan instansi terkait lainnya.

Terakhir pada Negara Samoa Barat, pada lembaga adat Fono model yang dipergunakan dengan bentuk Ifonga dan tindak pidana yang diselesaikan terhadap jenis perkara pencurian, perkelahian, pembunuhan dan perzinahan serta yang terlibat untuk menyelesaikannya adalah pelaku, korban dan masyarakat.

Dari perspektif global, regional dan nasional, mediasi penal lewat peradilan/lembaga adat, telah dilaksanakan. Untuk konteks Indonesia, peradilan adat/lembaga adat, sesuai nilai-nilai Pancasila yang dikedepankan. Apabila lewat peradilan adat atau lembaga adat tidak dapat diselesaikan, barulah perkara tersebut diselesaikan lewat sistem peradilan pidana, mulai dari pihak kepolisian, kejaksaan, peradilan dan lembaga pemasyarakatan. Oleh karena itu, di sini dikenal adanya kerjasama atau sinergitas antara sub sistem peradilan pidana dengan peradilan adat atau lembaga adat yang dikenal sebagai model Hybrid Justice System. Penerapan ini merupakan salah satu model dari penjabaran nilai-nilai restorative justice.

(c) Hendaknya Mahkamah Agung mengeluarkan Peraturan Mahkamah Agung (Perma) agar para hakim dalam segala tingkatannya menerapkan mediasi penal dalam perkara tertentu

Pada hakikatnya, berdasarkan 
Undang-Undang Nomor 3 Tahun 2009 tentang Mahkamah Agung ditentukan mempunyai beberapa kewenangan dan fungsi. Disamping berwenang mengadili sebagai peradilan kasasi, maka Mahkamah Agung juga mempunyai fungsi peradilan (justitiele function) yaitu sebagai peradilan negara tertinggi, melakukan pengawasan atas perbuatan pengadilan dalam menjalankan kekuasaan kehakiman juga fungsi mengatur (regelende functie).

Dalam menjalankan fungsi ini, Mahkamah Agung dapat mengatur halhal yang diperlukan bagi kelancaran penyelenggaraan peradilan baik terdapat hal-hal yang belum cukup diatur dalam Undang-Undang tentang Mahkamah Agung dan Mahkamah Agung dapat membuat peraturan acara sendiri bilamana dianggap perlu untuk mencukupi hukum acara yang sudah diatur Undang-Undang.

Tolok ukur mediasi penal sebagai salah satu bentuk menekan penumpukan perkara yang terdapat di Mahkamah Agung dan peradilan di bawahnya. Konsekuensi logisnya, jika para pihak dapat menyelesaikan sendiri sengketa/perkara tanpa harus diadili oleh hakim, sehingga jumlah perkara ke pengadilan akan berkurang pula. Untuk itu diperlukan adanya lembaga yang mengatur proses, mekanisme dan substansi untuk dilakukan mediasi penal.

Hakikatnya, diperlukan adanya suatu Perma yang mengatur, memberikan payung hukum dan akhirnya untuk dilaksanakan pada peradilan bawahannya dimana untuk perkaraperkara tertentu seperti perkara ringan, kerugian kecil, KDRT, perkara HAM, perkara lalu lintas, sengketa medis, sebelum adanya undang-undang, dapat dilakukan mediasi penal. Selain itu, idealnya Perma juga mengatur perangkat hukum dan infrastruktur berupa adanya lembaga hukum khusus untuk melakukan mediasi penal, kemudian ruangan atau sarana untuk melaksanakan mediasi penal serta diperlukan adanya orang yang akan melakukan mediasi penal (mediator) dapat berupa penegak hukum (polisi, jaksa, hakim), toga, todat dan tomas. Keahlian harus dimiliki mediator dalam melakukan mediasi penal oleh karena dimensi ini berbeda dengan mediasi dalam perkara perdata.

Apabila diperbandingkan antara mediasi perdata dengan mediasi penal dapat dikaji dari beberapa perspektif. ${ }^{19}$ Fokus utama mediasi perdata adalah permasalahan dan kesepakatan, akan tetapi pada mediasi penal adalah dialog dan hubungan. Apabila dilihat persiapan para pihak dalam konflik, pada mediasi perdata mediator tidak boleh menghubungi para pihak sebelum mediasi dimulai sedangkan pada mediasi penal setidaknya sekali pertemuan tatap muka mediator dengan masing-masing pihak sebelum pertemuan bersama. Kemudian dari peran mediator maka pada mediasi perdata tujuannya mengarahkan dan membimbing para pihak untuk mencapai kesepakatan yang memuaskan sedangkan mediasi penal menyiapkan korban dan pelaku agar mempunyai harapan yang realistis dan merasa cukup aman untuk berdialog secara langsung. Berikutnya, dari perspektif gaya mediator pada mediasi perdata aktif dan kadang sangat mengatur, sering berbicara dan bertanya dalam sesi mediasi sedangkan mediasi penal sangat tidak mengatur (non-directive) selama mediasi dan para pihak yang mengontrol semuanya. Kemudian dari konteks menghadapi emosi dalam

19 vide lebih detail dalam: I Made Agus Mahendra Iswara. 2013. Jakarta: Mediasi Penal Penerapan..., Ibid., hlm. 55 
konflik mediasi perdata terdapat toleransi yang rendah terhadap curahan perasaan terkait latar belakang konfllik sedangkan mediasi penal adalah mendorong curahan perasaan dari para pihak dan mendiskusikan latar belakang konflik. Terakhir, dari aspek kesepakatan tertulis maka mediasi perdata merupakan tujuan utama yang ingin dicapai sebagai hasil mediasi sedangkan pada mediasi penal merupakan target sekunder dimana yang primer adalah dialog dan saling membantu.

3. Kontribusi Mediasi Penal Sebagai Perwujudan Nilai-Nilai Pancasila Terhadap Supremasi Hukum dan Kontribusi Supremasi Hukum Terhadap Pembangunan Nasional

a. Kontribusi Mediasi Penal Sebagai Perwujudan Nilai-Nilai Pancasila Terhadap Supremasi Hukum

Kondisi sistem peradilan pidana dewasa ini dipelbagai negara muncul kepermukaan adanya rasa ketidakpuasan dan frustasi terhadap eksistensi hukum pidana formal. Aspek tersebut dikarenakan perkembangan sistem peradilan pidana dianggap tidak lagi dapat memberikan perlindungan terhadap hak asasi manusia serta transparansi terhadap kepentingan umum. Konsekuensinya, timbul gagasan bagaimana melakukan upaya alternatif untuk mengatasinya.

Perserikatan Bangsa-Bangsa (PBB) setiap lima tahun sekali menyelenggarakan kongres yang dikenal dengan nama "Congress on Crime Prevention and The Treatment of Offenders". Kongres ini bertujuan membicarakan dan mendiskusikan tentang perkembangan kejahatan, penanggulangannya dan penanganan pelaku kejahatan serta berbagai topik terkait. Dalam konggres tersebut juga diberi kesempatan bagi sejumlah negara untuk berbagi pengalaman atas sejumlah program. Dalam kesempatan ini, sejumlah negara juga mempergunakan kesempatan untuk mengadakan kerjasama dalam upaya pencegahan dan penanggulangan kejahatan terutama dalam kejahatan yang dilakukan lintas negara (transnational crime). Banyak implikasi positif bila dilakukan implementasi mediasi penal sebagai perwujudan nilai-nilai Pancasila. Pertama, penumpukan perkara tidak terjadi di pengadilan, sehingga secara ekonomis pengeluaran keuangan dan perekonomian negara tidak terjadi dan mengurangi waktu yang diperlukan untuk menyelesaian suatu perkara pidana. Korelasi dimensi ini, karena penumpukan perkara tidak terjadi maka lembaga pemasyarakatan relatif tidak menjadi overload. Kedua, dari perspektif korban membantu mengurangi rasa balas dendam terhadap pelaku, oleh karena antar individu telah terjalin tali silaturahmi kembali. Pelaku meminta maaf dan korban telah memaafkan sehingga mengurangi rasa bersalah pelaku dan tercipta suasana rekonsiliasi yang merupakan pencerminan asas musyawarah mufakat, sehingga kehidupan berbangsa dan bernegara menjadi selaras, serasi dan seimbang. Kemudian juga, tekanan terhadap korban berkurang dibanding jika berperkara di pengadilan, oleh karena tidak perlu menjadi saksi, membawa saksi, menyewa pengacara, dan mendapat kesempatan untuk mengontrol hasilnya. Ketiga, dari perspektif pelaku tidak pidana akan terhindar dari pemidanaan, stigma atau catatan kejahatan yang telah diperbuat, didenda atau biaya perkara sebagai ganti kerugian, dan lain 
sebagainya. Keempat, merupakan media serta kesempatan antara korban dan pelaku untuk bertemu membicarakan kejahatan yang dilakukan pelaku yang telah memberi stigma negatif dalam kehidupan korban, kemudian pula korban dapat mengungkapkan perhatian, keinginan dan perasaannya serta meminta restitusi. Kelima, dari perspektif normatif, nilai-nilai mediasi penal yang berasaskan Pancasila dan keadilan restoratif, yang apabila diimplementasikan dalam kebijakan legislasi maka aturan hukum relatif dapat diterima masyarakat karena diambil, diangkat, diterapkan dan berorientasi dari kandungan nilai-nilai budaya yang lahir, hidup, tumbuh dan berkembang dalam masyarakat Indonesia. Keenam, dilakukannya mediasi penal penanganan perkara menjadi lebih fleksibel, proses lebih cepat, sederhana dan hemat biaya dibandingkan prosedural panjang peradilan in caqu sesuai dengan sistem peradilan pidana yang berlaku selama ini.

\section{b. Kontribusi Supremasi Hukum Terhadap Pembangunan Nasional} Pembukaan UUD 1945 alinea kedua menyebutkan bahwa, "Dan perjuangan pergerakan kemerdekaan Indonesia telah sampailah kepada saat yang berbahagia dengan selamat sentosa mengantarkan rakyat Indonesia ke depan pintu gerbang kemerdekaan negara Indonesia, yang merdeka, bersatu, berdaulat, adil dan makmur." Kemudian dalam Pembukaan UUD NRI Tahun 1945 disebutkan bahwa, "pembangunan bangsa Indonesia adalah melindungi segenap bangsa Indonesia dan seluruh tumpah darah Indonesia dan untuk mewujudkan kesejahteraan umum, mencerdaskan kehidupan bangsa dan turut serta menciptakan perdamaian dunia yang berdasarkan perdamaian abadi dan keadilan sosial".

Dilatarbelakangi tolok ukur cita-cita yang tertuang dalam kalimat "adil dan makmur", maka pembangunan telah dipilih sebagai satu-satunya cara yang dianggap paling tepat untuk membawa bangsa Indonesia kearah kemakmuran. Dalam hal ini, pemerintah sejak tiga dasawarsa terakhir telah menjadikan pembangunan dibidang ekonomi sebagai tulang punggung pembangunan nasional. Sikap suatu pemerintah dapat terlihat dari kebijakan-kebijakan yang dikeluarkan oleh pemerintahan tersebut untuk mencapai kepentingan nasional negaranya.

Hakikat dan substansi pembangunan dilaksanakan dalam segala sendi-sendi kehidupan berbangsa, bernegara dan secara berkelanjutan. Salah satu sasaran pembangunan adalah aspek hukum itu sendiri. Pembangunan hukum sangatlah dibutuhkan untuk meneruskan perjuangan sebagai bangsa merdeka dan berdaulat sehingga memerlukan hadirnya eksistensi hukum nasional yang mencerminkan nilai-nilai budaya bangsa. Pembangunan hukum pada dasarnya meliputi usaha mengadakan pembaruan pada sifat dan isi dari ketentuan hukum serta usaha-usaha bagi pembentukan hukum baru yang diperlukan dalam pembangunan masyarakat.

Sistem Hukum Indonesia memasuki babak baru dalam perkembangannya. Salah satu bentuk pembaruan hukum adalah pengaturan perspektifdan pencapaian keadilan kepada perbaikan maupun pemulihan keadaan setelah peristiwa yang dikenal dengan keadilan restoratif. Dimensi ini sejalan teori 
hukum progresif dimana hendak mengokohkan keistimewaan "hukum" agar sedianya tetap bertahan dalam masa yang panjang. Pembangunan hukum nasional merupakan keniscayaan dan mesti diterima oleh bangsa Indonesia. Hal ini merupakan konsekuensi dari kondisi sebagai negara dengan memiliki tingkat kemajemukan masyarakat dan pluralitas sosial yang kompleks.

Hakikat supremasi hukum dan pembangunan nasional adalah keadilan dalam korelasinya terhadap pembangunan manusia Indonesia seutuhnya yang berbudi luhur. Oleh karena itu, kontribusi supremasi hukum terhadap pembangunan nasional sama-sama saling berintikan keadilan. Di satu sisi, supremasi hukum memerlukan kestabilan dan dukungan dari kesinambungan pembangunan. Sebaliknya, pembangunan nasional yang akan dirasakan oleh segenap lapisan masyarakat hakikatnya memerlukan perangkat norma dan supremasi hukum yang kuat.

Konsekuensi logisnya, adanya kontribusi keberhasilan supremasi hukum akan berpengaruh terhadap pembangunan nasional, sehingga diperlukan sinergitas diantara keduanya demi kehidupan berbangsa dan bernegara.

\section{Penutup}

\section{Simpulan}

Implementasi Undang-Undang Mediasi Penal penting eksistensinya menyelesaikan perkara di luar pengadilan. Substansi mediasi penal lahir, tumbuh, berkembang dan digali dari bumi Indonesia lewat kearifan lokal hukum adat (local wisdom) dan nilai-nilai Pancasila. Di Indonesia, dalam perspektif nasional mediasi penal diatur secara terbatas dan parsial dalam Peraturan dan Surat Kapolri serta Peraturan Menteri. Dari perspektif praktik, mediasi penal dilakukan lewat diskresi aparat penegak hukum, peradilan adat, yurisprudensi Mahkamah Agung dan putusan Pengadilan Negeri. Apabila Undang-Undang Mediasi Penal tidak dapat diwujudkan maka mengakibatkan penumpukan perkara terjadi di pengadilan sehingga secara ekonomis pengeluaran keuangan negara dan perekonomian negara meningkat. Kemudian, proses penanganan perkara menjadi lebih panjang dan rumit, peradilan pidana lebih bersifat retributif dan bukan restoratif sehingga lembaga pemasyarakatan menjadi overload, masyarakat Indonesia bersifat individualistis ketimbang kekeluargaan dan mengkedepankan musyawarah mufakat.

Dimensi belum membudayanya penyelesaian perkara melalui kearifan lokal dengan mediasi penal karena pemahaman masyarakat di Indonesia mengidentikkan penyelesaian permasalahan hukum lewat aparat penegak hukum sehingga bersifat legal positivistik. Penyelesaian perkara oleh masyarakat ditempuh melalui sistem peradilan pidana yang diatur dalam Undang-Undang Nomor 8 Tahun 1981 tentang Kitab Undang-Undang Hukum Acara Pidana (KUHAP). Hakikat penyelesaian perkara dalam konteks ini diharapkan memberikan kepuasan terhadap salah satu pihak yang berperkara atau juga memberi efek jera (detterent effeck) pada pelaku kejahatan, akan tetapi faktanya banyak menimbulkan problematika ketidakadilan. Penyelesaian perkara melalui sistem peradilan pidana yang berujung pada vonis pengadilan merupakan suatu penegakan hukum ke arah jalur lambat. Hal tersebut dikarenakan penegakan hukum melalui jarak tempuh yang panjang. Bentuk penyelesaian dilakukan jalan musyawarah melalui mediasi penal antara pihak pelaku dan korban akan menciptakan keseimbangan dan harmonisasi sosial dalam kehidupan bermasyarakat, berbangsa dan bernegara. Prinsip win-win solution 
harus diutamakan demi tercapainya kesepakatan menyelesaikan perkara.

Diperlukan adanya optimalisasi penerapan nilai-nilai Pancasila dalam hukum karena nilai-nilai yang hidup tersebut secara keseluruhannya termaktub pada sila-sila Pancasila. Adagium klasik menyebutkan bahwa ubi societas ibijus yaitu dimana ada masyarakat disitu ada hukum. Konsekuensinya, hukum akan mengandung nilai keadilan apabila diterapkan kepada masyarakat dimana hukum tersebut digali dari nilai-nilai yang hidup pada masyarakat bersangkutan sebagai jiwa bangsa (volksgeist/living law). Apabila hal ini dilakukan, hukum bersangkutan relatif dapat diterima oleh karena masyarakat mengganggap bahwa hukum mencerminkan nilai keadilan, kepastian hukum, ketertiban dan mengandung kemanfaatan bagi masyarakat sehingga dapat mendukung supremasi hukum dalam rangka pembangunan nasional.

Diperlukan pembentukan infrastruktur yang mendukung mediasi penal melalui lembaga hukum dengan mengharmonisasikan sistem peradilan pidana sehingga dimungkinkan adanya alternatif lain penyelesaian perkara pidana. Dimensi konteks tersebut akan berhasil apabila terjalin sinergitas antara Pemerintah, DPR RI, Mahkamah Agung, Kementerian, Tokoh Agama, Tokoh Adat, Tokoh Masyarakat, Aparat Penegak Hukum (Kepolisian/Kejaksaan) dan Komponen Masyarakat melakukan sosialisasi, komunikasi, koordinasi, pelatihan, gakkum, kurikulum pendidikan tentang betapa penting eksistensi mengimplementasikan mediasi penal dalam kehidupan bermasyarakat, berbangsa dan bernegara guna mendukung supremasi hukum dalam rangka pembangunan nasional.

\section{Saran}

Untuk mendukung implementasi mediasi penal sebagai perwujudan nilai-nilai Pancasila agar dapat berjalan dengan baik, maka diajukan beberapa saran sebagai berikut:

a. Mahkamah Agung dan seluruh badan peradilan di bawahnya, Kejaksaan Agung dan Kepolisian bersama Pemerintah Pusat dan Pemerintah Daerah melakukan menejemen pembinaan hukum tentang pentingnya penyelesaian permasalahan hukum melalui jalur mediasi penal agar terjadi keseimbangan dalam kehidupan di masyarakat dengan memperhitungkan dan mempertimbangkan eksistensi hukum yang tumbuh dan berkembang dikalangan masyarakat.

b. Kementerian Dikdasmen melakukan koordinasi dengan Kementerian Ristek, Teknologi dan Pendidikan Tinggi untuk mendesain program pendidikan dan kurikulum untuk merevitalisasi nilainilai Pancasila, serta mendorong Perguruan Tinggi untuk meningkatkan kegiatan pengkajian, penelitian, dan pengembangan implementasi Pancasila, waktu yang dibutuhkan selama setahun serta tahapan pelaksanaan melalui pengkajian, penelitian dan pengembangan di perguruan tinggi selama setahun, selanjutnya dimonitoring dan dievaluasi untuk perbaikan di tahun selanjutnya.

c. Presiden membuat Peraturan Pemerintah Pengganti Undang-Undang (Perpu) atau Peraturan Presiden (Perpres) tentang perkara pidana tertentu dapat dilakukan mediasi penal sehingga penumpukan perkara, ovoload lembaga pemasyarakatan, dan ekses negatif lainnya tidak terjadi dalam sistem peradilan pidana Indonesia.

d. DPR dan Presiden membuat peraturan tentang eksistensi mediator dalam melakukan mediasi penal dibiayai negara. 


\section{DAFTAR PUSTAKA}

Barda Nawawi Arief. 2008. Mediasi Penal Penyelesaian Perkara Di Luar Pengadilan. Semarang: Penerbit Undip

Elfina L. Sahetapy. 2015. Restorative Justice Dalam Wujud Diversi: Kasus Anak Yang Berkonflik Dengan Hukum. Jakarta: RajaGrafindo Persada.

Harahap, Hazairin Alamsyah. 1981. Tujuh Serangkai Tentang Hukum. Bandung: Angkasa

H. Lalu Parman. 2011. Mediasi Penal Dalam Sistem Peradilan Pidana Indonesia. Mataram: Paper.

I Made Agus Mahendra Iswara. 2013. Mediasi Penal Penerapan Nilai-Nilai Restorative Justice Dalam Penyelesaian Tindak Pidana Adat Bali, Jakarta: Tesis.

Lemhannas RI. 2016. Modul Bidang Studi Pancasila dan UUD NRI 1945, Jakarta: Lemhannas RI Program PPRA LIV.

Lemhannas RI. 2016. Modul BS Geopolitik dan Wawasan Nusantara, Jakarta: Lemhannas RI Program PPRA LIV.

Lemhannas RI. 2016. Modul BS Geostrategi dan Ketahanan Nasional, Jakarta: Lemhannas RI Program PPRA LIV.

Lemhannas RI. 2016. Materi Pokok Bidang Studi Hukum \& HAM. Jakarta: Lemhannas RI Program PPRA LIV.

Lemhannas RI. 2015. Buku Induk Nilai-nilai Kebangsaan Yang Bersumber Dari Empat Konsesus Dasar Bangsa. Jakarta: Lemhannas RI Program PPRA LIV.

Lawrence W. Friedman. 1984. New York: American Law: An invaluable guide to the many faces of the law, and how it affects our daily our daily lives.

Lilik Mulyadi. 2015. Mediasi Penal Dalam Sistem Peradilan Pidana Indonesia. Bandung: PT Alumni.

L.B. Curzon. 1979. Jurisprudence. Amerika Serikat: Paper.

Mark William Baker. 1994. "Repairing The Breach and Reconciling the Discordant: Mediation in the Criminal Justice System”, artikel pada North Corolina Law Review, No. 72 Tahun 1994.

Muchsan. 1985. Hukum Tata Pemerintahan. Yogyakarta: Liberty

Muladi. 2011. Implementasi Restorative Justice di Pengadilan Anak Indonesia, Majalah Hukum Varia Peradilan, Tahun XXVI No. 306 Mei 2011. Jakarta: Ikatan Hakim Indonesia (IKAHI).

Otje Salman dan Eddy Damian. 2002. Konsep-Konsep Hukum dalam Pembangunan. Bandung: PT Alumni.

Ridwan Mansyur. 2010. Mediasi Penal Terhadap Perkara Pidana KDRT (Kekerasan Dalam Rumah Tangga). Jakarta: Yayasan Gema Yustisia Indonesia.

Stuart M. Widman. 2006. "The Protections and Limits of Confidentiality in Mediation", artikel pada Alternatives to the High of Ligislation.

Suharso dan Ana Retnoningsih. 2014. Kamus Besar Bahasa Indonesia Edisi Lux. Semarang: Widya Karya

Umi Rozah. 2012 :"Konstruksi Politik Hukum Mediasi Penal Sebagai Alternatif Penyelesaian Perkara Pidana": Hukum Pidana Dalam Perspektif. Denpasar: Pustaka Larasan. 